I Universidade Estadual de Campinas (Unicamp), Departamento

de Sociologia, Campinas, SP, Brasil

rortiz@terra.com.br

https://orcid.org/00oo-0003-0246-5576

Renato Ortiz'

\title{
ORDEM/DESORDEM EM TEMPOS DE PANDEMIA
}

A pandemia do coronavírus coloca em suspenso a ordem social e, de uma certa forma, nos interpela em nossa condição intelectual. O que significa ordem qual o sentido de sua ruptura? Os antropólogos estão familiarizados com os rituais de liminaridade e de inversão que existem em diversas culturas e se manifestam em diferentes momentos da vida em sociedade. Um exemplo: a cerimônia zulu que antecede o plantio. Nessa ocasião, reverencia-se a deusa que ensinou aos humanos a arte de plantar e colher. Participam do ritual apenas as mulheres, que ao alterar suas condutas habituais, infringem uma série de tabus costumeiros: conduzem o gado (atividade exclusivamente masculina), carregam os escudos dos guerreiros, algumas vezes andam nuas e cantam cantigas impudicas. Os homens permanecem nas choças e, se por acaso saem, são por elas atacados. Outro exemplo: a entronização de um novo rei na Costa do Marfim. Um cativo-rei, escolhido entre os servos, exerce temporariamente as funções reais de dominação sobre os homens livres. Os cativos vestem sungas suntuosas, banqueteiam-se, bebem em abundância, afrontam as normas sagradas e ridicularizam os nobres da corte. Entretato, logo após o funeral do rei, o "poder rebelde" se desfaz; rasgam-se as tangas de seda e o cativo-rei é executado (Balandier: r 969). Os exemplos poderiam ser multiplicados, mas eles transcendem à sua particularidade: os rituais de inversão são mecanismos simbólicos de reforço da ordem social. Após um momento de liminaridade, de "caos", quando o quotidiano das coisas é abalado, tudo retorna ao normal e o 
status quo é preferível à desordem, ele se impõe (Gluckman: I963). Algo análogo ocorre nas sociedades modernas; os mecanismos de inversão da ordem não se restringem às culturas indígenas (como se o passado fosse uma dimensão revoluta). Um exemplo: os filmes de catástrofes. Neles, a narrativa organiza-se em três etapas: na primeira apresenta-se a ordem quotidiana das coisas, na segunda, sua destruição, na terceira, o retorno à vida normal. O elemento que dispara o gatilho da destruição pode variar: um ser monstruoso (King Kong), uma catástrofe ambiental (avalanche, terremoto, maremoto etc.), uma epidemia (ebola); de uma certa forma, ele é arbitrário, importa encontrar um dado convincente capaz de direcionar a história a ser relatada. As narrativas de catástrofe são bastante padronizadas, seguem um esquema de exposição simples e funcionam como um ritual de inversão no qual o ordenamento das coisas é temporariamente interrompido. O espectador, no conforto da poltrona do cinema, contempla o desmoronamento a distância; ele não o atinge, é ritualmente controlado pela estrutura do relato.

A pandemia implica diretamente uma quebra do quotidiano. Entretanto, se nos rituais de inversão esta é apenas simbólica, agora, é a realidade, em sua materialidade, que é colocada em xeque. Não se trata de questionar a noção de ordem em contraponto à desordem; é sua "essência" que entra em colapso. Todo ritual implica ordem, e por isso existem especialistas que o administram da maneira correta (feiticeiros, mágicos, sacerdotes), tudo e todos conhecem o seu devido lugar. O cativo-rei, no exemplo anterior, ou as mulheres insubmissas, no caso zulu, desempenham um papel determinado por um script que os transcende e os guia. Suas ações são previsíveis, pertencem a uma memória coletiva que ordena os gestos e as intenções. O ritual controla a "rebelião" resguardando-a em seu simbolismo discrepante. A situação de pandemia é distinta; nela a desordem é desregrada. A racionalidade das sociedades modernas entra em crise diante da imprevisibilidade dos acontecimentos. A ideia de gestão (controle racional das ações) se debilita: as indústrias, o comércio, os hospitais, o transporte, o fluxo das mercadorias, tudo, por um momento, se torna "irracional”, ou seja, aleatório, fortuito. Não há cura para o mal. Os diagnósticos científicos apenas tocam sua superficialidade; as "previsões", fundadas em ensaios matemáticos e experiências epidemiológicas, dizem respeito aos possíveis cenários de contaminação, mas a ameaça permanece, não é eliminada, precisa ser contida, sem entretanto existir um desfecho definitivo para tanto. A solução oferecida pelos rituais de inversão era reconfortante, assegurava simbolicamente a permanência das coisas; com a pandemia, a instabilidade predomina sobre a segurança. Ela é ainda global, não se restringe a uma área ou região do mundo; o planeta é o solo de sua desolação. Não há forma de fugir ao risco, ele é inexorável (Ianni: I996). Nesse sentido, o fechamento das fronteiras nacionais não é um mergulho em si mesmo, espécie de afirmação do local em contraponto ao global; pelo contrário, elas se cerram devido à globa- 
lização do vírus. Nada há de "nacionalismo" nessa opção de encerramento, ela é um artifício reativo, de salvaguarda, significa uma dependência e não uma autonomia em relação às ameaças.

Os rituais de rebelião têm uma qualidade; ao inverter a ordem quotidiana, tornam visíveis alguns mecanismos "estruturantes" das sociedades. Nos exemplos que utilizei fica clara a relação de subordinação entre masculino e feminino, dominantes e dominados; o que se encontrava latente, oculto, adquire uma feição manifesta. Algo semelhante ocorre na situação de pandemia; alguns "pilares" da vida social, que nos pareciam naturais, imanentes, são explicitados em sua denegação. Um elemento importante diz respeito à ideia de circulação. Os sociólogos afirmam ser essa uma dimensão específica às sociedade modernas. Contrariamente às sociedades tradicionais, agrárias, nas quais o movimento de pessoas e mercadorias era restrito, reduzido, com a modernidade há um "desenraizamento" das coisas. Elas deixam de pertencer a um lugar geográfico (o vilarejo, a região) para circular em escala ampliada. Um exemplo: o advento da Revolução Industrial e da modernidade no século XIX. À medida que o peso da tradição se debilita, amplia-se aceleradamente a circulação de coisas, objetos, pessoas. É o caso das reformas urbanas (Paris do barão Hauss mann; Rio de Janeiro de Pereira Passos), a emergência dos transportes públicos (bondes e ônibus, primeiro puxados por cavalos, depois, movidos a eletricidade), a mobilidade intraclasses, a migração do campo para a cidade, o incremento do comércio nacional e internacional. As inovações técnicas, trens, automóveis, navios, telégrafo e, posteriormente, cinema, rádio e televisão, farão da circulação um traço permanente de nossas vidas (particularmente na situação de globalização). A pandemia traz com ela algo de uma contramodernidade. Há primeiro uma restrição dos movimentos: fechamento de aeroportos, diminuição do comércio, interdição das viagens etc. O fluxo de pessoas e produtos é moderado em escala global. O isolamento, e não a mobilidade, torna-se uma virtude, única alternativa para se deter o avanço da doença. É preciso se recolher para que a desordem existente "lá fora" não nos atinja. Outra dimensão essencial deve ser ainda preterida: o indivíduo. Ele é uma espécie de emblema da modernidade (Simmel: I989). Com a Revolução Industrial e as revoluções políticas do século XIX o indivíduo transforma-se em símbolo de liberdade. Cada um, segundo suas crenças e necessidades, escolheria sua religião, sua ideologia, suas vestimentas - um dos éditos da Revolução Francesa dizia: a partir de agora qualquer homem ou mulher pode se vestir da maneira que quiser (Perrot: I98I). A liberdade individual, política ou social, não deveria ser cerceada, representaria a expressão máxima de um direito e de uma condição garantidos a todos (ideal que não se confirma na prática). Com o desenvolvimento de uma sociedade de consumo esse traço idiossincrático se reforça (Baudrillard: 1970), o lema, "I want and I want it now", revela a expectativa de conjunção entre os desejos pessoais e sua realização. A pandemia inverte essa relação de autono- 
mia. Ela é um "fato social" - utilizo a definição de Durkheim (I995) -, isto é, um evento exterior ao indivíduo que a ele se impõe de maneira coercitiva. Dela não podemos escapar. Por isso predomina entre nós um sentimento de frustração, ansiedade e medo. A sensação de impotência prevalece sobre a ação; recolhidos no isolamento olhamos o mundo a distância sem nele interferir. A aspiração individual cede lugar às exigências coletivas de preservação da vida (usos de máscara, quarentena, lockdown).

Os rituais de inversão pertencem às sociedades marcadas por um tempo cíclico; o presente, ou seja, a tradição, deve ser mantido a qualquer custo (esse é o papel dos mitos). A desordem simbólica é apenas o sinal de sua permanência. Nas sociedades modernas a mudança é o elemento decisivo. A epidemia, entretanto, paralisa a marcha do tempo, abre uma brecha entre o agora e o depois. Uma fissura se instaura diante da imprevisibilidade das coisas, como se o destino escapasse de nossas mãos. Ao ruir aquilo que conhecíamos resta a indefinição. $O$ atual que parecia tão sólido (dizia-se que a sociedade de entretenimento privilegiava o presenteísmo) se desfaz. Na situação de pandemia a ordem é colocada em suspenso (não é anulada), e o tempo acelerado de nossas vidas torna-se lento, moroso. Vive-se a espera. Há duas maneiras de se olhar este hiato entre temporalidades distintas. A primeira é valorizar o retorno a uma vida "normal", ao que existia antes. Os problemas existentes (são inúmeros, da injustiça à desigualdade) seriam sublimados, minimizados diante da desorganização vigente. Porém, os prognósticos para o futuro não são os melhores, a epidemia implica consequências nefastas (desemprego, aumento da pobreza, fome, destruição de empresas etc.). O presente almejado revela o gosto amargo de sua redenção, ele é incompleto, insatisfatório. Mas a fissura entre o hoje e o amanhã pode ser entendida como uma situação de liminaridade na qual a ordem das coisas, ao ser rompida, nos permitiria imaginar um outro mundo, uma maneira de viver distinta da atual. A quebra do quotidiano funcionaria assim como estímulo à imaginação utópica, e, mesmo sabendo ser esta uma condição onírica, encontraríamos um mundo inteiramente diferente. Uma janela se abriria no horizonte, e o fim do "fim das utopias" nos libertaria das malhas do presente.

Recebido em 25/I I/2020 | Aprovado em 06/05/202I

Renato Ortiz é professor titular do Departamento de Sociologia da Unicamp e pesquisador IA do CNPq. Tem doutorado pela École des Hautes Études en Sciences Sociales (Paris) e publicou diversos livros, entre eles A moderna tradição brasileira, O universo do luxo e Sobre o 


\section{REFERÊNCIAS}

Balandier, Georges. (1969). Antropologia política. São Paulo: Difel.

Baudrillard, Jean. (I970). La société de consommation. Paris: Denoel.

Durkheim, Émile. (I995). As regras do método sociológico. São Paulo: Martins Fontes.

Gluckman, Max. (1963). Custom and conflict in Africa. Oxford: Basil Blackwell.

Ianni, Octávio. (1996). A era do globalismo. Rio de Janeiro: Civilização Brasileira.

Perrot, Philippe. (I98I). Le dessus et les dessous de la bourgeoisie: une histoire du vêtement au XIXe siècle. Paris: Fayard. Simmel, Georg. (1989). L'individualisme moderne. In: Philosophie de la modernité. Paris: Éditions Payot. 


\section{ORDEM/DESORDEM EM TEMPOS DE PANDEMIA}

\section{Resumo}

O artigo faz uma reflexão sobre a noção de ordem social no contexto da pandemia da covid-ig. Argumenta que a disseminação do vírus contém uma dimensão de contramodernidade, uma vez que elementos centrais da modernidade clássica (século XIX) são colocados em causa, particularmente a questão do isolamento e da mobilidade.

\section{ORDER/DISORDER IN PANDEMIC TIMES}

\section{Abstract Keywords}

The article has the intention to think about the notion of social order in the covid-I9 pandemic context. The argument is that dissemination of the virus encloses a dimension of counter-modernity, so far central elements of classical modernity (XIX century) are adjourn, mainly those referred to isolation and mobility.
Social order; pandemic; modernity.
Palavras-chave

Ordem social;

pandemia;

modernidade. 